\title{
OBSERVATIONS ON THE MOBILIZATION OF PEAT NITROGEN IN INCUBATION EXPERIMENTS
}

\author{
JAAKko KivekäS and ERKKi Kivinen \\ Department of Agricultural Chemistry. University of Helsinki.
}

Received July 12, 1959

Peat lands contain considerable amounts of nitrogen, which for the main part however, occurs in such organic compounds as are not easily soluble and are slow in mobilizing, being thus scarcely or not at all available to plants. The mobilization of the natural supply of nitrogen into a form available to plants would thus be of considerable economic advantage in the cultivation of peat lands. KaILA, Sorni and Kivinen (3) have investigated the effects of calcium, fertilizers, and ash on the mobilization of nitrogen, and state that calcium as a rule stimulated the nitrification, but on the amount of mineral nitrogen calcium has in general a negative effect. The effect of ash was, according to them, apparent mainly as a neutralizing quality. They did not observe any clear effect of trace elements, nor of calcium or phosphorus fertilizers. Having investigated the effect of lime on the accumulation of mineral nitrogen in incubation experiments with peat soils KaILA and SorNI (5) states that liming does not always enhance the accumulation of mineral nitrogen, nor does it always cause an increase in the nitrate nitrogen. KIvinen (7) has in some experiments noted that liming and fertilizing clearly enhances the mobilization of peat nitrogen. KAILA, KöYLIJÄRVI and KIVINEN (2) found that a higher temperature increased the amounts of ammonium nitrogen, though they might be caused by purely chemical phenomena. Since all the above mentioned investigations into the mobilization of peat nitrogen have been carried out with only comparatively few samples, it was decided to continue research by using more extensive material.

\section{Material and methods}

The material of this study consisted of 60 samples from peat soils in North Finland. All the samples were air-dried and ground with a Willey-mill.

The $\mathrm{pH}$ was measured in water and $\mathrm{N} \mathrm{KCl}$ suspensions (1:4) using a Beckman $\mathrm{pH}$-meter with glass electrode.

The ammonium nitrogen was extracted with an $0.1 \mathrm{~N} \mathrm{HCl}$. The ammonium nitrogen was determined by shaking samples of fresh incubated peats weighing 20 grams in $100 \mathrm{ml}$ of $0.1 \mathrm{~N} \mathrm{HCl} \mathrm{for} \mathrm{one}$ hour, and by filtrating and washing the peat twice with $25 \mathrm{ml}$ of the extractant. The ammonia in the extract was determined by distillation with $\mathrm{MgO}(5)$. 
The soluble organic nitrogen was determined from the original samples by burning, in accordance with the Kjeldahl-method, a part of the solution obtained in determining the ammonium nitrogen and by distilling the nitrogen from this. The obtained amount of nitrogen minus the amount of ammonium nitrogen was taken as representing organic nitrogen.

The nitrate nitrogen was extracted from fresh samples of $20 \mathrm{~g}$ with $100 \mathrm{ml}$ of a CaSO, solution in which the samples were shaken for ten minutes. The determination was made from the filtrate by the phenoldisulphonic acid method (1) using an EEL-colorimeter.

The presence of nitrite nitrogen was determined with Griess' reagent.

Also the amounts of calcium and potassium extractable with a $\mathrm{N} \mathrm{NH}_{4} \mathrm{Cl}$ solution were determined by adding $100 \mathrm{ml}$ of this solution to $2 \mathrm{~g}$ of air-dried peat. The liquid was filtered through paper and the determination was made by using a Lange flamephotometer (4).

Some characteristics of the peat samples are reported in Table 1 . There are 20 samples in which the $\mathrm{Sph}$ a $\mathrm{g} \mathrm{n} \mathrm{m}$ remains are dominant; the other 40 samples represent peat where the $\mathrm{C}$ a r e $\mathrm{x}$ remains are dominant.

Table 1. Peat samples.

\begin{tabular}{|c|c|c|c|c|c|c|c|c|c|c|c|}
\hline No & $\mathrm{H}$ & $\begin{array}{c}\text { Depth } \\
\mathrm{dm}\end{array}$ & $\begin{array}{c}\text { Weight } \\
\text { of } \\
\text { volume }\end{array}$ & $\begin{array}{c}\text { Ash } \\
\%\end{array}$ & $\mathrm{pH}_{\mathrm{H}_{2} \mathrm{O}}$ & $\mathrm{pH}_{\mathrm{KCl}}$ & $\begin{array}{c}1 \mathrm{~N} \mathrm{NH}_{4} \mathrm{Cl} \\
\text { exchange- } \\
\text { able } \\
\mathrm{Ca} \%\end{array}$ & $\begin{array}{c}\text { Total } \\
\mathrm{N} \\
\%\end{array}$ & $\begin{array}{c}\mathrm{NH}_{4}-\mathrm{N} \\
\mathrm{g} / \mathrm{kg}\end{array}$ & $\begin{array}{c}\mathrm{NO}_{3}-\mathrm{N} \\
\mathrm{g} / \mathrm{kg}\end{array}$ & $\begin{array}{c}\text { Min. N } \\
\mathrm{g} / \mathrm{kg}\end{array}$ \\
\hline
\end{tabular}

$\begin{array}{rrrrrrrrrrrr}9 & 0-1 & 0-2 & 0,16 & 9.9 & 4,9 & 4.1 & 0.52 & 1.95 & 0.20 & 0.33 & 0.53 \\ 1 & 1 & 0-2 & 0.14 & 9.0 & 5.5 & 4.5 & 1.05 & 2.52 & 0.13 & 0.35 & 0.48 \\ 10 & 1-2 & 2-4 & 0.24 & 15.6 & 5.2 & 4.1 & 0.37 & 2.97 & 0.11 & 0.21 & 0.32 \\ 2 & 3 & 3-5 & 0.28 & 7.5 & 5.2 & 4.3 & 0.86 & 2.75 & 0.14 & 0.38 & 0.52 \\ 3 & 7 & 7-9 & 0.34 & 4.4 & 5.3 & 4.2 & 0.68 & 2.76 & 0.12 & 0.10 & 0.22 \\ 11 & 7 & 5-7 & 0.37 & 10.6 & 5.0 & 3.9 & 0.40 & 3.62 & 0.14 & 0.20 & 0.34\end{array}$

Samples of $\mathrm{Cp}_{\mathrm{p}}$

$\begin{array}{rcccrccccccc}29 & 1-2 & 5-7 & 0.20 & 5.1 & 4.6 & 3.9 & 0.37 & 1.99 & 0.17 & 0.15 & 0.32 \\ 44 & 3 & 1-2 & 0.34 & 16.4 & 4.5 & 3.9 & 0.45 & 3.12 & 0.26 & 0.18 & 0.44 \\ 13 & 3-4 & 1-3 & 0.28 & 5.1 & 4.9 & 4.0 & 0.39 & 3.47 & 0.13 & 0.25 & 0.38 \\ 14 & 3-4 & 5-7 & 0.26 & 4.9 & 5.1 & 4.1 & 0.34 & 2.67 & 0.19 & 0.17 & 0.36 \\ 25 & 3-4 & 1-3 & 0.21 & 4.5 & 4.6 & 3.7 & 0.34 & 2.33 & 0.17 & 0.25 & 0.42 \\ 26 & 3-4 & 5-7 & 0.20 & 3.1 & 4.2 & 3.7 & 0.35 & 2.40 & 0.18 & 0.24 & 0.42 \\ 40 & 3-4 & 1-3 & 0.29 & 10.9 & 5.8 & 4.6 & 0.39 & 3.06 & 0.09 & 0.17 & 0.26 \\ 43 & 3-4 & 0-1 & 0.35 & 11.1 & 4.9 & 4.1 & 0.50 & 3.12 & 0.22 & 0.29 & 0.51 \\ 45 & 3-4 & 0-1 & 0.31 & 5.6 & 4.9 & 4.2 & 0.71 & 3.60 & 0.25 & 0.56 & 0.81 \\ 46 & 3-4 & 1-2 & 0.33 & 2.3 & 4.1 & 3.6 & 0.60 & 3.20 & 0.24 & 0.36 & 0.60 \\ 51 & 3-4 & 0-2 & 0.27 & 5.3 & 4.8 & 3.7 & 0.46 & 2.94 & 0.23 & 0.17 & 0.40 \\ 52 & 3-4 & 0-2 & 0.29 & 4.7 & 4.4 & 3.8 & 0.54 & 2.98 & 0.18 & 0.37 & 0.55 \\ 36 & 5 & 4-6 & 0.34 & 6.1 & 4.9 & 3.8 & 0.37 & 2.54 & 0.10 & 0.08 & 0.18 \\ 55 & 5 & 0-2 & 0.23 & 8.8 & 4.8 & 4.0 & 0.56 & 3.62 & 0.15 & 0.16 & 0.31 \\ 56 & 5 & 0-2 & 0.27 & 8.4 & 4.7 & 3.7 & 0.55 & 3.78 & 0.19 & 0.15 & 0.34 \\ 41 & 5-6 & 2-6 & 0.28 & 3.5 & 4.2 & 3.7 & 0.39 & 3.61 & 0.21 & 0.09 & 0.30 \\ 20 & 6 & 6-8 & 0.30 & 4.8 & 5.4 & 4.3 & 0.38 & 2.88 & 0.18 & 0.16 & 0.34 \\ 4 & 6-7 & 3-6 & 0.35 & 6.6 & 5.2 & 4.1 & 1.35 & 2.73 & 0.14 & 0.09 & 0.23 \\ 19 & 7-8 & 3-5 & 0.46 & 8.1 & 5.4 & 4.3 & 0.34 & 3.52 & 0.24 & 0.15 & 0.39 \\ 60 & 8-9 & 10-14 & 0.53 & 7.0 & 4.9 & 3.7 & 0.36 & 2.56 & 0.33 & 0.29 & 0.62\end{array}$


No $\mathrm{H}$ Depth Weight Ash $\mathrm{pH}_{\mathrm{H}_{2} \mathrm{O}} \mathrm{pH}_{\mathrm{KCl}} 1 \mathrm{~N} \mathrm{NH} \mathrm{H}_{4} \mathrm{Cl}$ Total $\mathrm{NH}_{4}-\mathrm{N} \quad \mathrm{NO}_{3}-\mathrm{N} \quad \mathrm{Min} . \mathrm{N}$

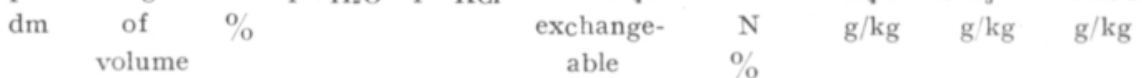
$\mathrm{Ca} \%$

Samples of $\mathrm{SC}_{\mathrm{p}}$

$\begin{array}{llllrlllllll}28 & 1 & 0-3 & 0.20 & 6.5 & 4.5 & 3.9 & 0.45 & 1.74 & 0.19 & 0.12 & 0.31 \\ 12 & 2-3 & 0-1 & 0.27 & 9.8 & 4.4 & 3.9 & 0.51 & 3.40 & 0.14 & 0.72 & 0.86 \\ 35 & 2-3 & 4-6 & 0.26 & 5.0 & 4.4 & 3.6 & 0.34 & 1.03 & 0.19 & 0.08 & 0.27 \\ 18 & 3-4 & 0-2 & 0.27 & 15.4 & 5.5 & 4.4 & 0.33 & 4.51 & 0.25 & 0.46 & 0.71 \\ 24 & 3-4 & 6-8 & 0.35 & 2.2 & 5.1 & 4.0 & 0.66 & 2.51 & 0.17 & 0.03 & 0.20 \\ 59 & 5-6 & 0-5 & 0.45 & 9.6 & 5.3 & 4.1 & 0.30 & 5.07 & 0.34 & 0.14 & 0.48\end{array}$

Samples of EuSCp

$\begin{array}{rccccccccccc}57 & 3 & 0-2 & 0.25 & 8.5 & 5.5 & 4.5 & 1.40 & 2.56 & 0.15 & 0.16 & 0.31 \\ 58 & 3 & 0-2 & 0.28 & 5.9 & 5.3 & 4.5 & 1.25 & 3.20 & 0.16 & 0.18 & 0.34 \\ 47 & 3-4 & 0-2 & 0.24 & 7.1 & 5.9 & 5.3 & 2.35 & 3.00 & 0.17 & 0.26 & 0.43 \\ 48 & 3-4 & 0-2 & 0.27 & 7.2 & 5.9 & 5.4 & 2.40 & 3.24 & 0.22 & 0.91 & 1.13 \\ 5 & 3-4 & 4-6 & 0.27 & 5.3 & 5.4 & 4.9 & 1.40 & 2.53 & 0.17 & 0.20 & 0.37\end{array}$

Samples of LC- and LSCp

$\begin{array}{cccccccccccc}27 & 4 & 11-14 & 0.23 & 5.3 & 4.4 & 3.7 & 0.29 & 2.04 & 0.22 & 0.27 & 0.49 \\ 23 & 4-5 & 4-6 & 0.32 & 2.0 & 5.0 & 4.0 & 0.79 & 2.37 & 0.17 & 0.05 & 0.22 \\ 30 & 5-6 & 2-5 & 0.34 & 4.7 & 4.8 & 3.9 & 0.36 & 2.73 & 0.18 & 0.10 & 0.28\end{array}$

Samples of CSp

$\begin{array}{rlrlrlllllll}15 & 1-2 & 0-2 & 0.26 & 10.3 & 4.4 & 3.5 & 0.30 & 2.44 & 0.29 & 0.40 & 0.69 \\ 16 & 1-2 & 0-2 & 0.21 & 8.5 & 4.3 & 3.6 & 0.30 & 2.67 & 0.10 & 0.38 & 0.48 \\ 17 & 1-2 & 0-2 & 0.18 & 6.5 & 4.4 & 3.6 & 0.34 & 2.11 & 0.16 & 0.51 & 0.67 \\ 38 & 2 & 2-4 & 0.23 & 5.0 & 4.6 & 3.0 & 0.43 & 2.23 & 0.62 & 0.21 & 0.83 \\ 49 & 2-3 & 0-2 & 0.18 & 4.8 & 4.5 & 3.6 & 0.49 & 3.03 & 0.20 & 0.27 & 0.47 \\ 50 & 2-3 & 0-2 & 0.22 & 4.3 & 4.3 & 3.6 & 0.50 & 3.25 & 0.12 & 0.25 & 0.37 \\ 53 & 3 & 0-2 & 0.23 & 5.6 & 4.6 & 3.8 & 0.46 & 3.26 & 0.18 & 0.12 & 0.30 \\ 54 & 3-4 & 0-2 & 0.26 & 4.1 & 4.6 & 3.8 & 0.50 & 3.03 & 0.16 & 0.13 & 0.29 \\ 39 & 3-4 & 4-6 & 0.25 & 4.3 & 4.6 & 3.1 & 0.35 & 2.12 & 0.28 & 0.21 & 0.49 \\ 8 & 4-5 & 3-4 & 0.39 & 5.5 & 4.6 & 3.9 & 0.39 & 2.41 & 0.09 & 0.23 & 0.32 \\ 33 & 5 & 6-8 & 0.25 & 5.8 & 4.5 & 3.3 & 0.44 & 2.61 & 0.21 & 0.08 & 0.29 \\ 42 & 6-7 & 2-4 & 0.39 & 12.4 & 3.9 & 3.3 & 0.30 & 2.37 & 0.13 & 0.09 & 0.22\end{array}$

Samples of Sp

$\begin{array}{rlllllllllll}6 & 0-1 & 1-2 & 0.11 & 4.2 & 4.5 & 3.6 & 0.70 & 1.19 & 0.12 & 0.47 & 0.59 \\ 21 & 0-1 & 0-2 & 0.09 & 8.0 & 4.3 & 3.1 & 0.62 & 0.85 & 0.21 & 0.08 & 0.29 \\ 31 & 0-1 & 0-2 & 0.08 & 5.9 & 4.2 & 2.9 & 0.41 & 2.44 & 0.21 & 0.14 & 0.35 \\ 32 & 0-1 & 4-6 & 0.08 & 3.9 & 4.4 & 3.0 & 0.47 & 1.46 & 0.23 & 0.16 & 0.39 \\ 34 & 0-1 & 0-2 & 0.09 & 5.0 & 4.2 & 3.4 & 0.34 & 1.03 & 0.20 & 0.37 & 0.57 \\ 37 & 1 & 0-2 & 0.11 & 4.9 & 4.5 & 3.1 & 0.49 & 1.45 & 0.21 & 0.17 & 0.38 \\ 71-2 & 2-4 & 0.17 & 4.5 & 4.6 & 3.8 & 1.06 & 1.49 & 0.19 & 0.20 & 0.39 \\ 22 & 1-2 & 2-3 & 0.14 & 2.8 & 5.0 & 4.1 & 0.68 & 1.15 & 0.17 & 0.09 & 0.26\end{array}$


The samples came from the surface layers of bogs as well as from layers deeper down. Consequently the degrees of humification differed relatively much. The volume weights and the amounts of ash indicate that there were no notable amounts of mineral matter in the samples, which is natural enough since the main part of the samples came from bogs in natural state situated rather far from roads etc. Most of the samples were clearly acid and the amounts of exchangeable calcium were low.

The amounts of total nitrogen were the same as are common in Finnish peats (6). The amounts of mineral nitrogen were rather high in most of the samples. The drying and grinding of the samples may be a reason for this, as has heen shown possible by KIVEKÄs (8) expressly where ammonium nitrogen is concerned.

No nitrite was found in the samples.

All the results have been calculated in relation to dry matter as $\mathrm{mg} / \mathrm{kg}$ or $\mathrm{kg} / \mathrm{ha}$ (to the depth of $20 \mathrm{~cm}$ ).

\section{The incubation experiments}

The object of the investigation was to elucidate the phenomena that appear in peat nitrogen under favourable conditions with regard to moisture and other circumstances. It is hardly necessary to emphasize that in a laboratory the conditions are considerably more favourable and regular than in the field, and since the samples had been dried and ground the results obtained are certainly not applicable to the natural processes in the field. Moreover, the arrangement of the experiments was such as to give an indication of the interaction between the different phenomena like ammonification, nitrification, and denitrification at the moment of analysis, but not to give any idea of the leaching or the influence of plants, etc. that take place in the field.

Each sample was ground and mixed and placed into four glass jars, each jar containing $50 \mathrm{~g}$. Of the four jars two were limed with an amount of lime correspond-

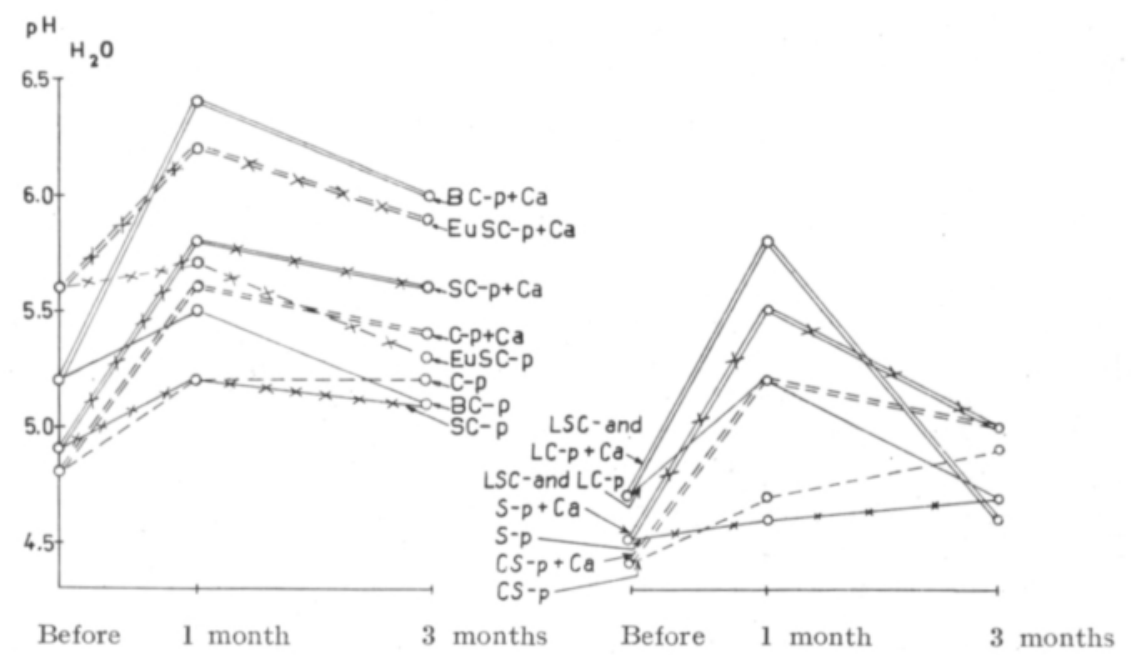

Figure 1. The effect of the incubation on the acidity of peat samples. 
Table 2. The effect of incubation on the $\mathrm{pH}_{\mathrm{H}_{2} \mathrm{O}}$ of peat samples

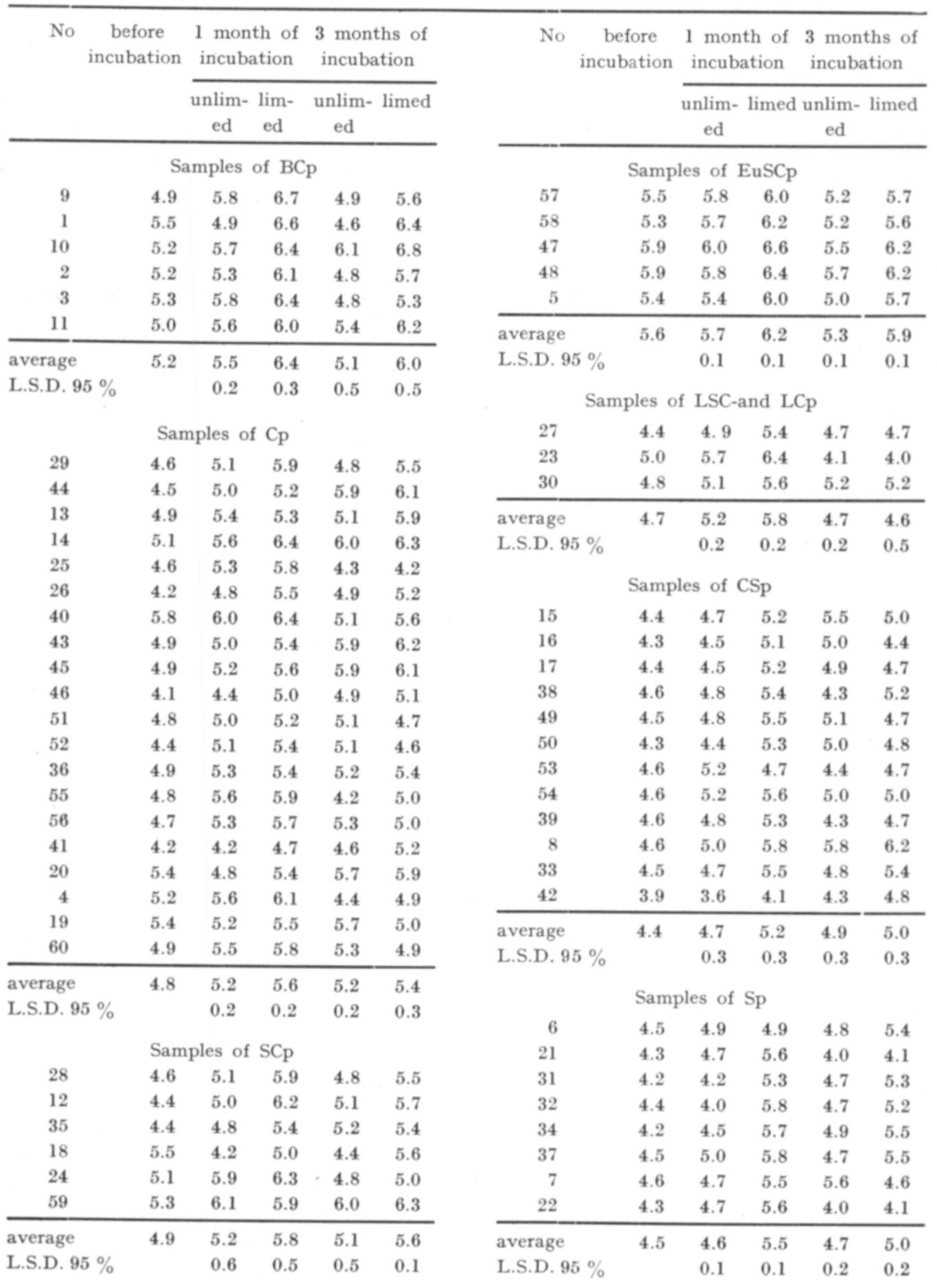


ing to 4 tons per hectare. The samples were moistened to a moisture degree of about 70 per cent. Water evaporating during the time of incubation was replaced by moistening performed at intervals. The moistened and well mixed samples were incubated at a mean temperature of about $17-18^{\circ} \mathrm{C}$. Although the optimal temperature for the nitrification organisms is higher, the above mentioned temperature was considered suitable mainly because it is easily available, and because it corresponds, at least to some extent, to conditions in nature. The contents of the jars were analysed after one month and three months of incubation. The $\mathrm{pH}$, the ammonium and the nitrate nitrogen were determined from a fresh sample. In Table 2 and in Figure 1 the effects of the incubation on the acidity are reported, the mean values are calculated per peat type, as well as the significant difference at 95 per cent level. In order to facilitate comparison the values determined before incubation have also been given in the tables.

The figures in Table 2 show that incubation during one month has in most cases caused a decrease in the acidity, although also a few contradictory cases are noted. In the limed samples the rise in the $\mathrm{pH}$ was greater than in the unlimed ones. After three months of incubation in part of the samples an increase in the acidity was to be seen, although the $\mathrm{pH}$ continued to be higher than the original $\mathrm{pH}$ value. On examining the effect of incubation on the acidity of the peat samples on the basis of the mean values it is evident that in all peat groups there was a rise in the $\mathrm{pH}$ during one month of incubation. The rise varies in unlimed samples by $0.1-0.5$ while in the limed samples it was $0.6-1.2 \mathrm{pH}$ degrees.

After three months of incubation the $\mathrm{pH}$ had sunk, although it was still higher than the original $\mathrm{pH}$ values in all the peat groups except the limed LC- and LSC peats. In the limed samples, with the exception of the LC and LSC peats, the pH was higher than in the unlimed samples.

In general the changes in the $\mathrm{pH}$ are very similar in all peat groups. Any clear differences between the different peat groups cannot be noted. The rise in the $\mathrm{pH}$ that occurs during the first month of incubation can probably be attributed to the ample formation of ammonia during the first stages of incubation, as KAILA and others (3) and KAILA and SorNi (5) have stated. Later, when the ammonia has changed into nitrate the $\mathrm{pH}$ sinks again.

Table 3 shows the effect of incubation on the amounts of ammonium and nitrate nitrogen. Examining the figures in this Table, one finds that this effect was very variable.

Since the variations are big even within one and the same type of peat, it is difficult to get a clear view of the matter by examining the values of the single samples. For this reason the mean values of the different types of peat have been calculated in Table 3. On the basis of these figures it can be stated, that an incubation of one month increased the amount of ammonium nitrogen in all peat groups except the SC peat groups, and that liming in some cases enhanced the forming of $\mathrm{NH}_{4}-\mathrm{N}_{\text {. }}$ A considerable decrease in the nitrate nitrogen can be noted, this being greater in the unlimed samples than in the limed ones.

If the amounts of ammonium nitrogen and nitrate nitrogen in the original samples and those in the incubated ones are compared, it will be found that in 


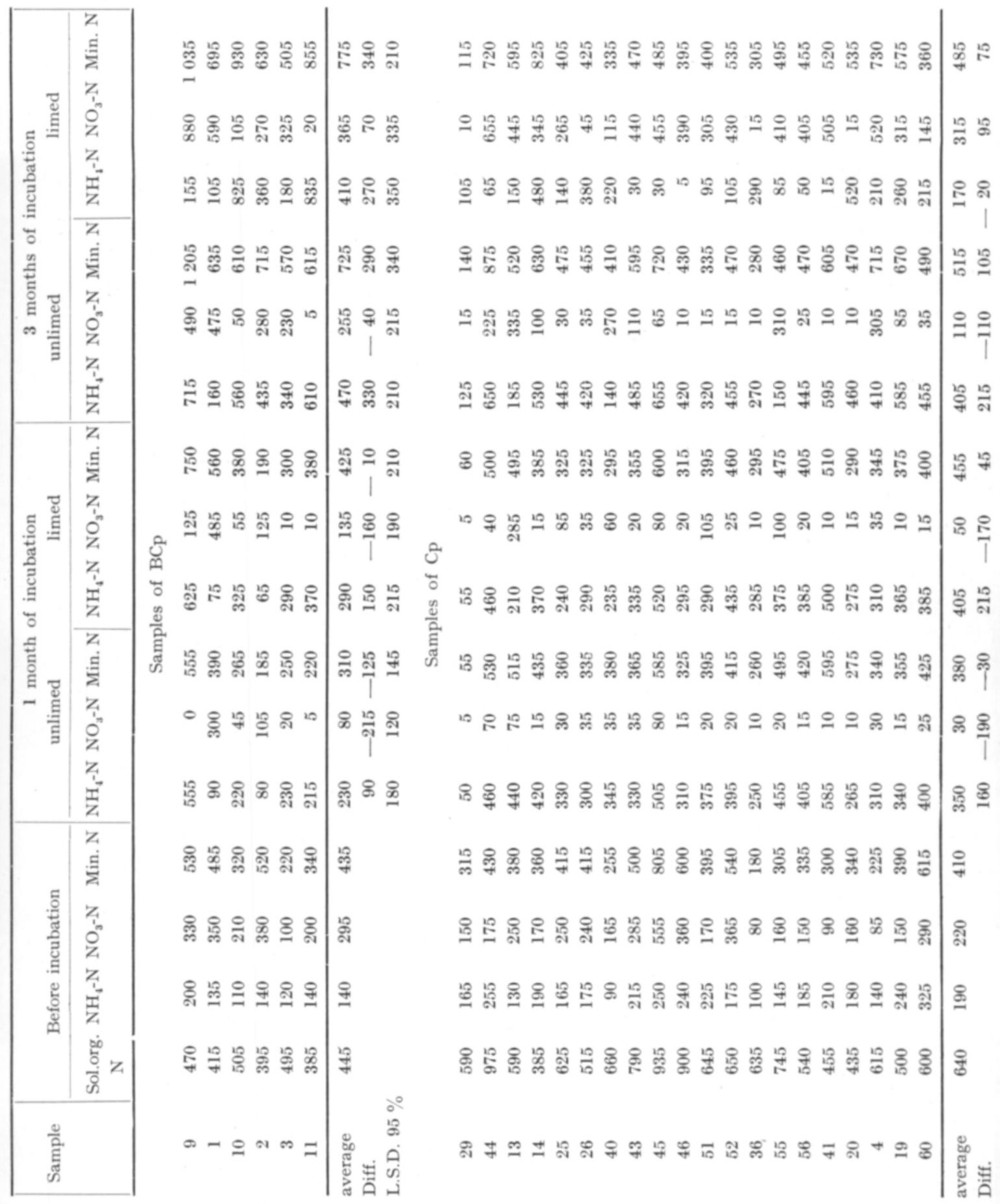




\begin{tabular}{|c|c|c|c|c|c|c|c|}
\hline 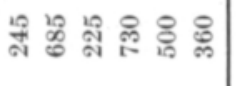 & 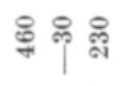 & & 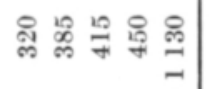 & 윰 융 & & $\begin{array}{lll}19 & 10 & 19 \\
5 & 0 & 0 \\
0 & 16 & 0\end{array}$ & 옥 \\
\hline 옹연 & สำ육 & & 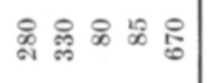 & 零品 品 & & $\stackrel{90}{9} \stackrel{10}{7}$ & 电厐 \\
\hline 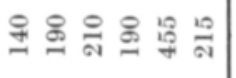 & 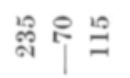 & & 암 음 & 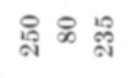 & & 佩 \& & 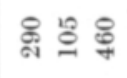 \\
\hline ๑ & $\stackrel{\infty}{\rightarrow} \stackrel{\ominus}{\ddagger}$ & & 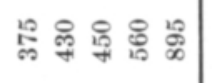 & 염 유용 & & 악눈 & 웍욘웍 \\
\hline 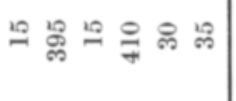 & 曷 & & 윯 융유 웅 & 늑용원 & & ตొ $\subseteq \cong$ & 융్ㅀ \\
\hline 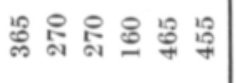 & 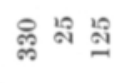 & & 요 \& \& & 윽위녹 & & 影总昜 & 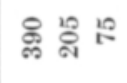 \\
\hline 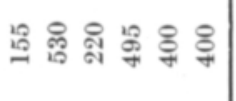 & 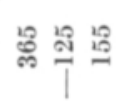 & & 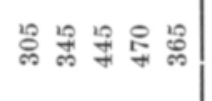 & 象 & & 요욣 & 量绐号 \\
\hline 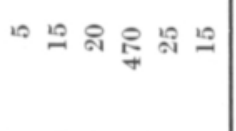 & 요용 & 芩 & 으ㅇㅛㅠ & 里 & త్త & 밀 요 10 & ํㅗำำ \\
\hline 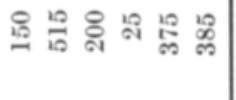 & 究 § & 范 & 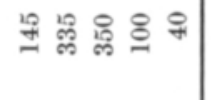 & 里 & 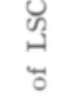 & 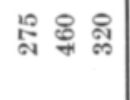 & 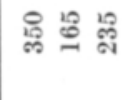 \\
\hline 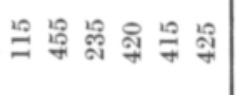 & 옹연 육 & 㯺 & 융 & 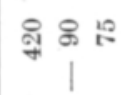 & 总 & 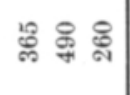 & 옹요 \\
\hline 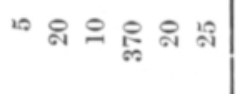 & 음음 & & 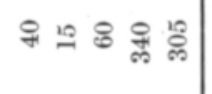 & 옹 $\frac{10}{1}$ & nू & ลำ 으 10 & 옥 ลำ \\
\hline 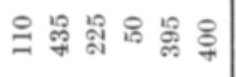 & 尽午只 & & 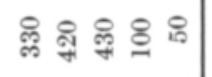 & ไี้ & & 융ํำ & 융요용 \\
\hline 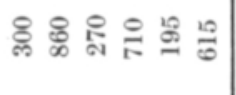 & \& & & 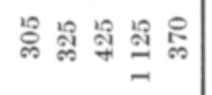 & $\frac{0}{16}$ & & か̊ำ 윳 & ศ్లి \\
\hline 요요 \& & $\stackrel{\infty}{\mathscr{0}}$ & & 통영영 & ํํํ & & 옹의 & $\stackrel{9}{2}$ \\
\hline 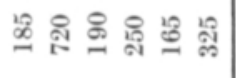 & gి & & 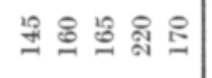 & $\stackrel{8}{=}$ & & 은은 & $\stackrel{10}{\circ}$ \\
\hline 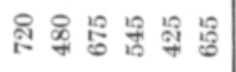 & की & & 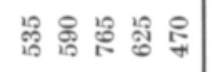 & 喿 & & มิำ & 只 \\
\hline 옹 요요 & 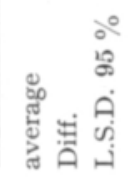 & & 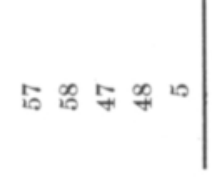 & 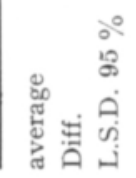 & & ล & đ․ \\
\hline
\end{tabular}




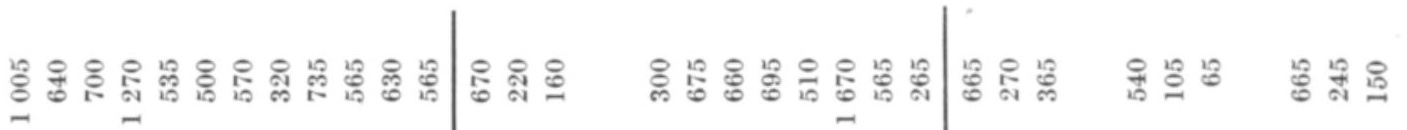

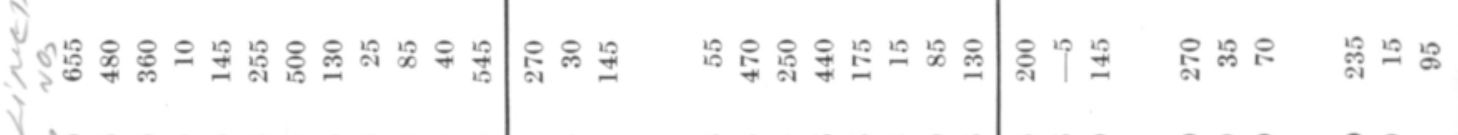

\begin{tabular}{|c|c|c|c|}
\hline$\circ 910$ & \& & 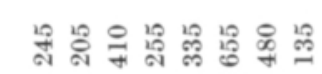 & 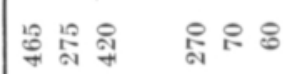 \\
\hline
\end{tabular}

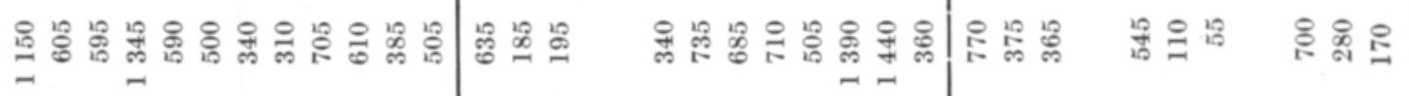

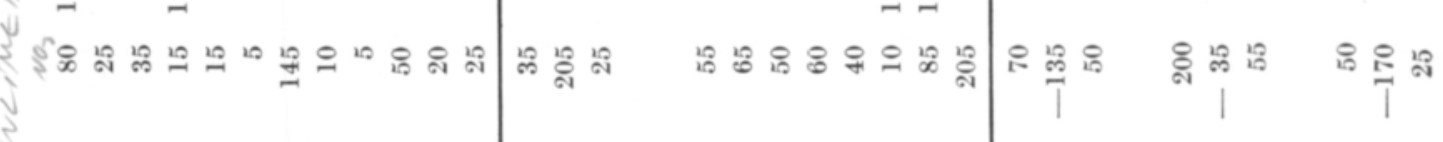

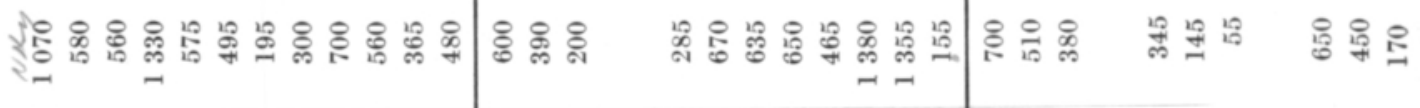

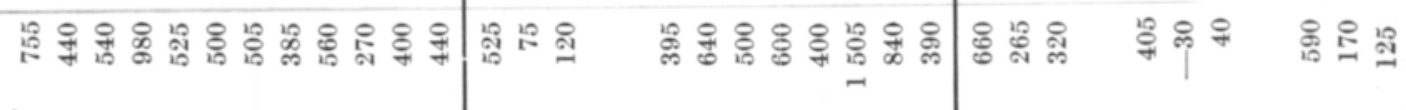

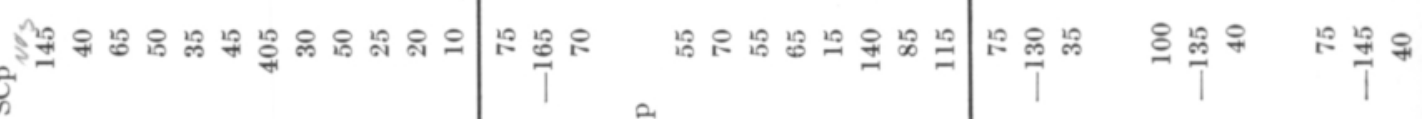

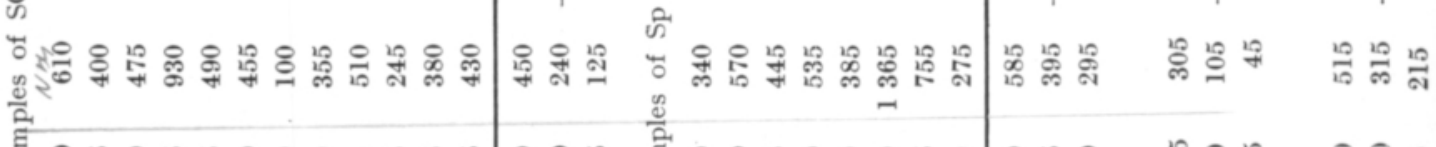

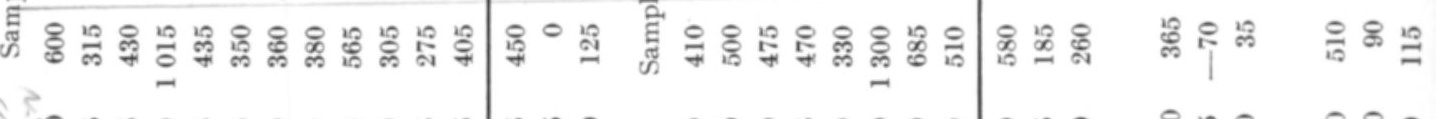

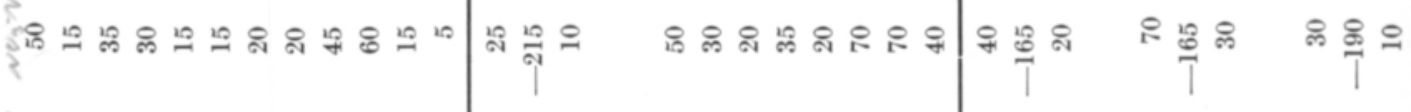

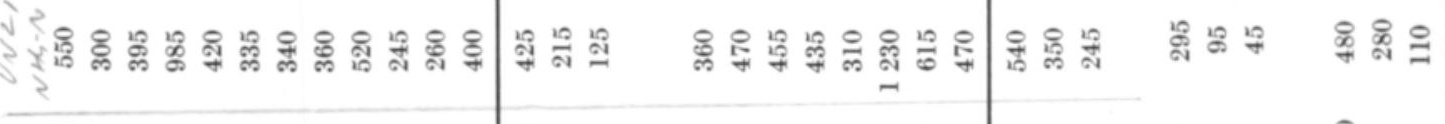

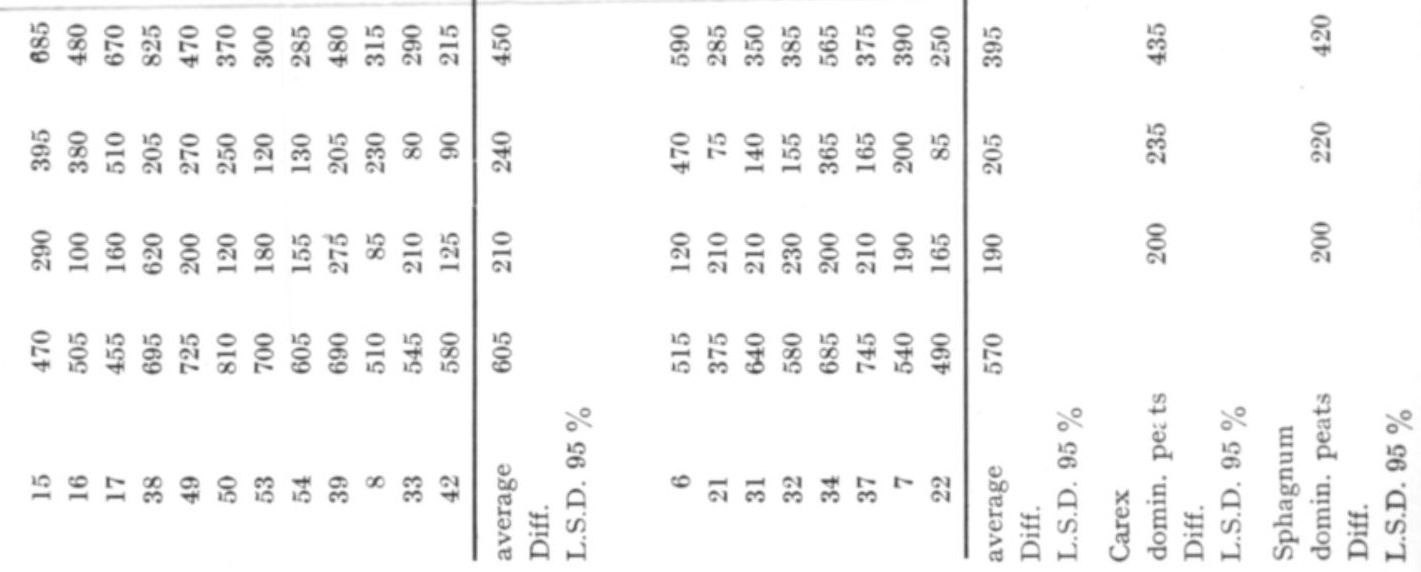


Carex-dominated peats, except in forest peats and limed Carex-dominated perts, a reduction in the amount of nitrogen has taken place. On the other hand, the amounts of ammonium nitrogen and nitrate nitrogen in Sphagnum peats are bigger in the incubated samples than in the original ones owing to the rich formation of ammonium nitrogen.

After three months of incubation it can be established that in the unlimed samples there is more ammonium nitrogen than in the original ones, excepting the EuSC-peats. In general there has been an increase also in comparison with the samples that have been incubating for one month only. There is still less nitrate nitrogen than in the original samples, although the amount is greater than in samples incubated for one month excepting again the EuSC-peats. In the limed samples that have been incubating for three months there is more ammonium nitrogen than in the original samples, with the exception of the $\mathrm{C}$ and $\mathrm{SC}$ peats, but in general the ammonium nitrogen content is smaller than in the unlimed samples. Of nitrate nitrogen there was found more in the limed samples after three months of incubation than in the original ones, excepting the EuSC and S peats. On examining the total amounts of ammonium nitrogen and nitrate nitrogen after three months of incubation it is found that they have increased in all peats except the SC peats. Liming has in some instances stimulated the mineralization.

In order to establish the effect of incubation on the Carex- and Sphagnumdominated samples the mean values of these two groups are given in Table 3 . The BC, C, EuSC, SC, LSC, and LC peats (altogether 40 samples) have been considered Carex-dominated, and the CS and S peats (altogether 20 samples) have been considered Sphagnum-dominated. In addition the possible increases or decreases in the amounts of mineral nitrogen as compared to the amounts in the original samples are also given. The results show that one month of incubation has in the Carexdominated samples caused an increase in the amount of ammonium nitrogen, the increase being slightly greater in the limed samples than in the unlimed ones. The amount of nitrate nitrogen bas decreased considerably after one month of incubation, the decrease being slightly larger in the unlimed samples than in the limedones. After three months of incubation the formation of ammonium nitrogen in the unlimed samples has continued. In the limed samples, again, there is now less ammonium nitrogen than in the samples that had been incubating only one month, nevertheless they still contain more ammonium nitrogen than the original samples. After three months of incubation the amount of nitrate nitrogen shows an increase as compared to what it was after one month, however, it is still slightly lower in the unlimed samples than in the original ones. In the limed samples, on the other hand, there is already slightly more nitrate nitrogen than in the original samples; accordingly liming has to some extent enhanced the forming of nitrate.

On the basis of these results it would seem that after one month of incubation the amount of ammonium nitrogen and nitrate nitrogen together in the Carex-dominated samples, limed as well as unlimed, is slightly smaller than in the original samples. After three months the amount is greater than in the original samples. Liming has neither caused a distinct increase, nor a decrease in the amount, to some extent it has, however, enhanced the formation of nitrate. In the Sphagnum-dominated 
samples one month of incubation has doubled the amount of ammonium nitrogen compared to the amount in the original samples; the increase is slightly larger in the limed samples. The amount of nitrate nitrogen has decreased considerably in the Sphagnum-dominated samples after one month of incubation. The decrease was smaller in the limed than in the unlimed samples. After three months the amount of ammonium nitrogen had further increased in the unlimed samples. In the limed samples, on the other hand, a decrease in the amount of ammonium nitrogen had taken place, although the amount is not nearly as small as in the original samples. The amount of nitrate nitrogen had increased also in the Sphagnum-dominated peats, true, only slightly in the unlimed samples, while in the limed ones the amount by now exceeded the amount of nitrate in the original samples. The total amount of ammonium nitrogen and nitrate nitrogen is clearly higher in the incubated samples, especially after three months of incubation, than in the original ones.

If the changes in the nitrogen compounds of these two peat types are compared, it will be seen that they very much resemble each other. It is interesting to note that in the original samples there were on an average, equal amounts of ammonium nitrogen and nitrate nitrogen in both groups. It is also interesting to find that after three months of incubation the total amounts of ammonium and nitrate nitrogen are distinctly higher in the Sphagnum-dominated than in the Carex-dominated samples. It should be noted, however, that in this connection the results have been counted on the basis of the weight units. If the volume units are taken as the means of comparison, for instance the mobilization in kilograms per hectare (Fig. 2), the Carex peats are found to be better mobilizers of nitrogen.

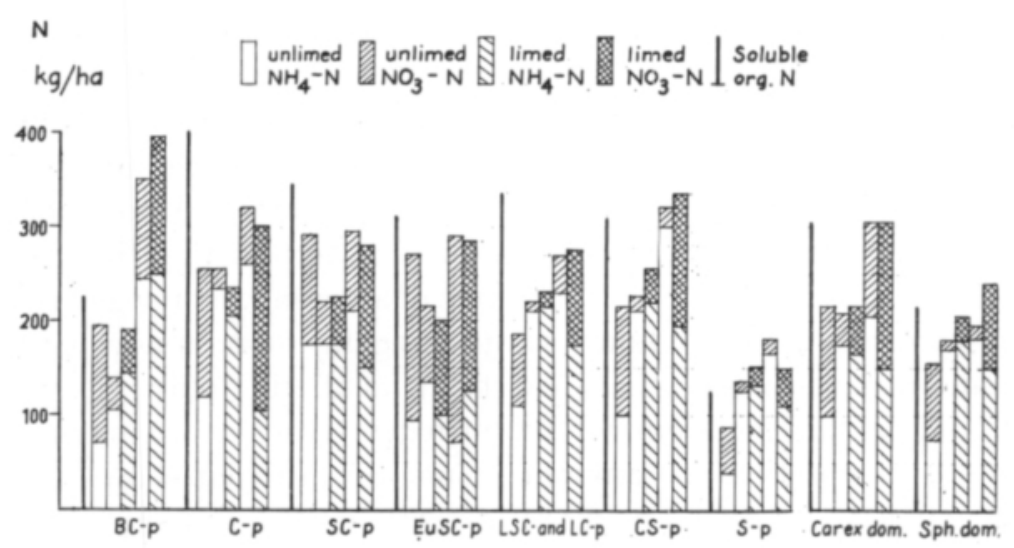

Figure 2. Mineral nitrogen in $\mathrm{kg} / \mathrm{ha}$ in different peat types. At each peat type the first pilars represent the orginal samples, the second and third pillars the situation after one month of incubation, and the fourth and fifth the situation after three months of incubation.

As regards the mobilization of nitrogen expressed in kg per ha as shown in Fig. 2 it is apparent that the mobilization is very similar in all peatgroups except the S-peats, whose mobilization ability is rather less than that of the other groups. On comparing Carex-dominated and Sphagnum-dominated peats it is found that 
slightly more nitrogen is mobilized from the Carex-dominated peats, the difference is noticeable especially after an incubation period of three months.

Since the material was fairly large and diverse it was considered justifiable to examine, using the correlation coefficient, to what extent the mobilization of nitrogen is dependent on other qualities in the samples. The coefficients werecalculated only for the Carex- and the Sphagnum-dominated peats. In a few cases, only, a significan correlation was obtained. Between the soluble organic nitrogen and the ammonium nitrogen in the limed Carex-dominated samples that had been incubating for three nonths a clear correlation was obtained $\left(0.553^{* * *}\right)$. A correlation was also obtained between the soluble organic nitrogen in the original samples and the mobilized nitrogen in the limed Carex-dominated samples that had been incubating for three months $\left(0.425^{* *}\right)$.

\section{Discussion:}

On the basis of the results it can be stated that in these experimental conditions the differences between the various peat types in the mobilization of nitrogen are fairly small. To draw a clear line between the different peat types is difficult, in part even impossible. The same observation has earlier been made by Kaila, Sorni and Kivinen (3). They have presumed that e.g. the low degree of humification in the peats could possibly account for the similarities. In this investigation, however, peats in many different stages of humification have been used, nevertheless no clear differences have been obtained. In addition the dispersions have been so great that even if there were in some cases differences between the mean values, the great dispersion makes them unreliable.

It is interesting to note that in samples that have been incubating for one month there is in many cases a smaller amount of mineral nitrogen than in the original samples. It is possible that there are many reasons for this, one of them might be the original great amount of extractable mineral nitrogen in the dried and ground samples. When the samples are moistened anew and are incubating, the effects of the drying and grinding might gradually disappear. The results obtained by KIVEKÄS (8) with regard to the effect of drying and grinding on the results of analyses, are an indication of this.

Liming seems in general to stimulate the nitrification. KaILA, Sorns and KIVINEN (3) have reached the same conclusion. This was particularly apparent in the samples after three months of incubation. On the other hand liming has seldom an increasing effect on the total amount of mineral nitrogen, even if one can not speak about a decreasing effect of liming, as has been stated by KaILA and SoINI (5).

A relatively interesting point is the fact that by dividing the peats into only two groups, the Carex-dominated and the Sphagnum-dominated peats, the total amount of mineralized nitrogen is found to be higher in the Sphagnum-dominated than in the Carex-dominated peats. This, however, holds good only if the results are calculated on the basis of the weight unit; if the volume unit is used the Carex peats seem to mobilize more nitrogen. 
Among the reasons for the similarity in the results obtained from different peats, the effect of the artificial conditions in a laboratory may be considered the most important one. The incubation experiments were carried out with dried and pulverized samples in room temperature and constant moisture conditions, in which the possible harmful effects of the physical differences in the peats were unable to exercise any influence. Moreover, in experiments of this kind the effects of plants and the washing down of nutrients are excluded; and, what is most important, in this kind of experiment only the final results of the phenomena are stated ( 3 and 5$)$. Thus the results obtained from these experiments are not directly applicable to conditions in the field.

\section{$S u m m a r y$}

60 peat samples from northern Finland representing different types of peat were incubated in a laboratory at a temperature of $17-18^{\circ} \mathrm{C}$. The ammonium nitrogen, the nitrate nitrogen and the $\mathrm{pH}$ in the samples were determined after one month of incubation as well as after three months of incubation. The results were compared to results from determinations made before incubation. An attempt was made to elucidate the factors that influence the mobilization of nitrogen.

On the basis of the above results it is evident that the differences between the various peat types as mobilizers of nitrogen are under these circumstances not very distinct, nor do these differences seem to be dependent on the types of peat. The following facts can, however, be established:

In the amounts of ammonium nitrogen an increase takes place in most groups of samples during the first month. This increase is fairly big in the Sphagnum-dominated peats.

The increase in ammonium nitrogen continues in the unlimed samples in most peat groups during all three months of incubation.

After three months of incubation the amount of ammonium nitrogen in the limed samples is smaller than in the unlimed samples, although it is usually bigger than in the original samples.

After the first month of incubation the amounts of nitrate nitrogen in all types of peat have decreased compared to the amounts in the original samples. In the limed samples the decrease is not as great as in the unlimed ones.

After three months of incubation the amount of nitrate nitrogen has considerably increased as compared to the amount after one month of incubation. In the limed samples it might to some extent exceed the original amount of nitrate nitrogen, however, this is seldom the case in the unlimed samples.

If the results are calculated on the basis of weight unit, it can be stated that the ability to mobilize nitrogen is greater in the Sphagnum peats than in the other peat groups.

Working out the results in $\mathrm{kg}$ per ha it will be noted that somewhat more nitrogen is mobilized in the Carex-dominated than in the Sphagnum-dominated peats.

The results obtained by experiments in the laboratory are not directly applicable to conditions in the field. 


\section{REFERENCES}

(1) Berge, T. O. 1941. Determination of nitrate-nitrogen with a photoelectric colorimeter. Soil Sci 52: $185-191$.

(2) Kaila, A., KöylijÄrvi, J. \& Krvinen, E. 1953. Influence of temperature upon the mobilisation of nitrogen in peat. J. Sci. Agr. Soc. Finland 25: 37-46.

(3) - - Sorni, S. \& Krvinen, E. 1954. Influence of lime and fertilizers upon the mineralization of peat nitrogen in incubation experiments. Ibid. 26: 79-95.

(4) _- \& KrveкÄs, J. 1956. Distribution of extractable calcium, magnesium, potassium and sodium in various depths of some virgin peat soils. Ibid. 28: 79-95.

(5) - $\quad \&$ SoINI, S. 1957. Influence of lime on the accumulation of mineral nitrogen in incubation experiments of peat soils. Ibid. 29: $229-237$.

(6) Krvinen, E. 1933. Suokasvien ja niiden kasvualustan kasvinravintoainesuhteista. Acta agr. fenn. 27.

(7) $\rightarrow$ 1954. Turpeiden typen mobilisaatiosta. Suo 4: 35-41.

(8) КтуекÄs, J. 1958. Turpeiden kuivaamisen ja jauhamisen vaikutuksesta analyysituloksiin. Summary: The effect of drying and grinding of peat samples on the results of analyses. J. Sci. Agr. Soc. Finland 30: 1-9.

S E L OS T US :

HAVAINTOJA TURPEEN TYPEN MOBILISAATIOSTA MUHITUSKOKEISSA

JАAKKо Krvekäs ja ERKKI Krvinen

Yliopiston maanviljelyskemian laitos, Helsinki

Laboratoriossa muhitettiin 60 pohjois-Suomen soilta otettua turvenäytettä $17-18^{\circ} \mathrm{C}$ lämpötilassa ja n. $70 \%$ kosteudessa, sekä seurattiin turpeessa $\mathrm{NH}_{4}-\mathrm{N}$ ja $\mathrm{NO}_{3}-\mathrm{N}$ määrien vaihteluja 1 ja $3 \mathrm{kk}$ pituisten koejaksojen kuluessa. Turpeiden välillä todettiin eroavaisuuksia, mutta ne eivăt noudattaneet turvelajeja. 